\title{
Evaluation of Shoot Cuttings Sources and Planting Distance to Increase the Production of G2 Potato Seed
}

\author{
Endeh Masnenah ${ }^{1 *}$, Nendah Siti Permana1, Ai Komariah', Ramdani Abdul Rahman ${ }^{2}$, Rohana \\ Abdullah $^{1}$ and Noertjahyani ${ }^{1}$
}

Date Received: $16^{\text {th }}$ December 2019 / Date Accepted: 01 ${ }^{\text {st }}$ February 2020

\begin{abstract}
Purpose : The availability of quality potato seed is one of the limiting factors to improve the yield and quality. The aim of this research was to obtain the second generation of potato seeds (G2) with the best growth and yield in combinations the sources of shoot cuttings and planting distance.

Research Method: The experiment used a factorial randomized complete block design with two factors: the sources of shoot cuttings (plantlet, G0, G1) and planting distance $(80 \mathrm{~cm} \times 15 \mathrm{~cm}, 80 \mathrm{~cm} \times 20 \mathrm{~cm}$ and $80 \mathrm{~cm} \times 25$ $\mathrm{cm})$ with three replications and the measured responses are component of growth and yield.

Findings: The results showed that the sources of shoot cuttings from G0 produced the highest percentage of growth $(97.72 \%)$, plant height $(81.68 \mathrm{~cm})$, canopy width $(33.87 \mathrm{~cm})$, maximum tuber weight per plant (237.27 gram), maximum tuber weight per plot $(4.15 \mathrm{~kg})$ and the highest number of tubers per plant (7.88) was obtained from the shoot cuttings sources of plantlet. Planting distance $(80 \mathrm{~cm} \times 25 \mathrm{~cm})$ tends to be better for tuber weight per plant (171.31 gram) and tuber weight per plot (2.81 kg).
\end{abstract}

Limitations : By using the shoot cuttings sources from plantlet it requires time to acclimatization.

Value : It is very important to evaluate of shoot cuttings sources (plantlet, G0, G1) and planting distance so to accelerate the availability of $G 2$ potato seeds in large quantities and quality, besides, using the shoot cutting sources can reduce production cost. The regulation of planting distance is the most important aspects of potato production.

Keywords: Potato, G2 seed, shoot cuttings, planting distance

\section{INTRODUCTION}

Potato (Solanum tuberosum L.) is the most important food crop after rice and wheat for human consumption as a vegetable commodity, food processing industry, as well as an alternative source of carbohydrate for food diversification (Salem and Hassanein, 2017Hermes, and Spunta, sterilized and subjected to shoot formation and propagation on Murashige and Skoog (MS; Harahagazwe et al., 2018) . Therefore, the demand of potatoes is increasing so that the production must be increased both in quantity and quality. Potato varieties which are widely cultivated in Indonesia are the Granola varieties. The productivity of potato in Indonesia was 15.4 ton ha $^{-1}$ with a total production of $1,164,738$ ton from a harvest area of 75,611 ha (Badan Pusat Statistik, 2017). This productivity is low as compared to the world.

The main obstacles to increase potatoes production are the availability of inadequate quality potato seeds and the distribution of seeds that have not been continuous (Karjadi, 2017). This is limiting the factor to use quality potato seeds for farmers. Potato can be propagated sexually (by botanical seed also called True Potato Seed) and asexually or vegetatively propagated using pieces or whole potato tubers,

\footnotetext{
Faculty of Agriculture, Winaya Mukti University, Indonesia. endehmasnenah@gmail.com

2 Indonesian Vegetables Research Institute.
}

(D) ORCID http://orcid.org/0000-0002-5301-7303 
but virus infection causes crop reduction to almost a half or even one third, which varies from place to place and from season to another (Dahshan et al., 2018); (Salem and Hassanein, 2017)Hermes, and Spunta, sterilized and subjected to shoot formation and propagation on Murashige and Skoog (MS. Consequently farmers use low quality and infected seed from previous potato crops without proper selection that has led to" high degeneration of seed tubers" due to systemic viral and bacterial diseases resulting in poor quality and quantity of potato tubers (Sibongile et al., 2014). One of the efforts to multiplication of potato seeds in large quantities and quickly is by rapid propagation techniques. According to (Harahagazwe et al., 2018) that, rapid multiplication techniques for potato seed production can be carried out with "In Vitro" conditions through the production of "plantlets and microtubers", that can also be done with "In Vivo" conditions through the production of "cuttings and minitubers". Minitubers can be produced through aeroponics and hydroponics, while "cuttings" can be produced by apical shoots, leaf-buds, single nodes and sprout tubers. Furthermore, (Yasmin and Zakaria, 2019) stated that the propagation of potatoes can use materials like sprout cuttings, top-shoot cuttings or stem segments with at least one bud and true potato seeds.

To accelerate the availability of second generation potato seeds (G2), then plantlets, G0 tuber and G1 tuber are propagated by "shoot cuttings" and then rooted to the rooting media and directly transplanting into the field area, so as to accelerate the production of second generation potato seeds (G2). G2 potato seeds are propagated from $\mathrm{G} 1$ seeds or propagated from a higher class of seeds ( $\mathrm{G} 0$ seed tubers or plantlet cuttings) and carried out in the field. Potato seed G0 (zero generation) belongs to the base seed class, G1 (one generation) belongs to the stock seed class and G2 belongs to the extension seed class (Direktorat Perbenihan Hortikultura, 2014). According to (Muthoni et al., 2017) that "Cuttings" can be made on planlets in the seedling tray so as to increase the number of plants without incurring tissue culture cost. Using potato seed propagation techniques expedites improving the efficiency of potato seed supplies, accelerate of seed availability and increase the number of seed quality (Karjadi, 2017). Furthermore (Muthoni et al., 2017) reported that stem cuttings propagation is among the most productive and highly efficient low cost potato multiplication procedures. Using stem cuttings, a single plantlet can yield up to 100000 progenies in 6 months. According to (Mamun et al., 2015) that by using top-shoot cuttings it can reduce production cost that would be used in potato production rather than the plant produced from whole tuber.

By using different spacing below or above recommendation is depending on purpose of planting either for consumption or for seed tuber. Therefore, it is important to maintain appropriate plant population per unit area to have high yield, marketable size, and good quality of seed tuber (Zerga et al., 2017). According to ( Hossain et al., 2015) that plant density in potato crop is regulated through the number and size of the seed tubers planted. The low population provides an advantage to the individual plants in access to water, nutrients and sunlight. The regulation of planting distance is the important aspect of potato production management because it affects the total cost of seed, growth, development, yield and quality of crop (Akassa et al, 2014)65, 70, 75, 80 and $85 \mathrm{~cm}$ and three levels of intra row spacings: 20,30 and $40 \mathrm{~cm}$.

\section{MATERIALS AND METHODS}

The experiment was conducted from February to May 2017 in the Experimental Garden of the Indonesian Vegetable Research Institute (IVEGRI), Cikole Village, Lembang District,West Bandung, West java Province, Indonesia. The ingredients consist of $300 \mathrm{knol}$ generation of G0 and G1 potato tubers and 30 bottle of plantlets as breedstock of shoot cuttings of Granola variety, husk charcoal , chicken manure (30 ton ha ${ }^{-1}$ ), ZPT auksin, NPK 16-16-16 (1 ton $\left.\mathrm{ha}^{-1}\right)$, alcohol, and pesticides.

The experiment used a factorial randomized 


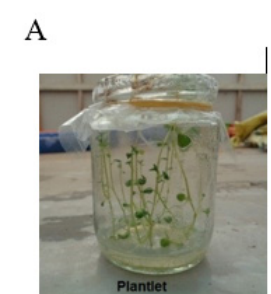

B

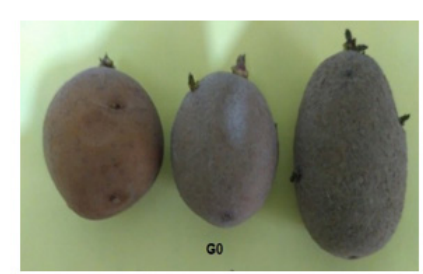

1
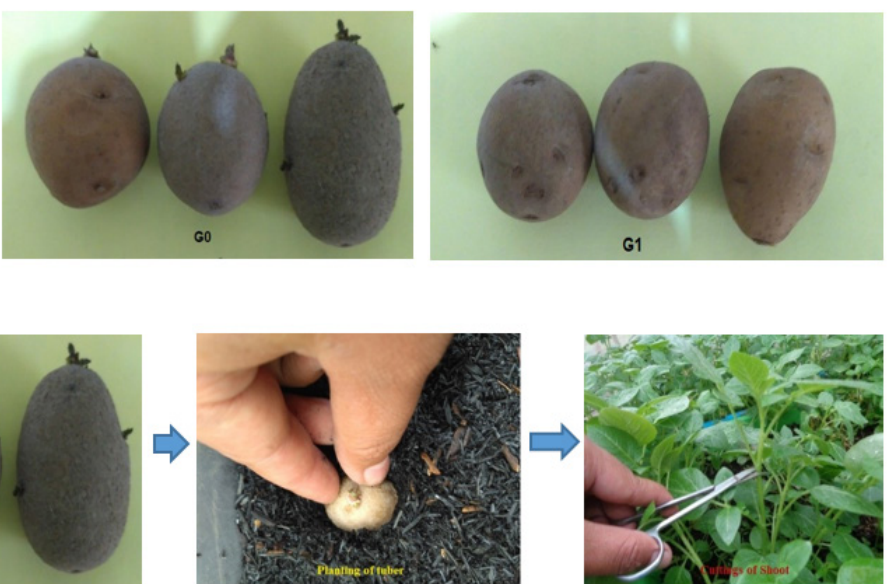

2

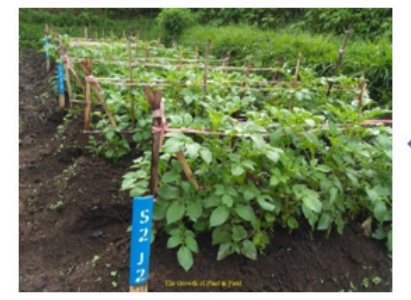

5
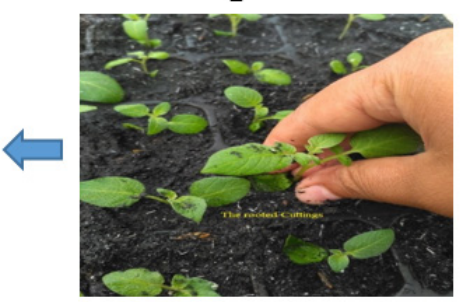

A. Sources of shoot cuttings; B. Preparation of Shoot cuttings sources from G0; 1. G0 tuber; 2. Planting of tuber; 3. Cuttings of shoot; 4. Rooted cuttings; 5. The growth of plant in field.

\section{Figure 01: Preparation of shoot cuttings sources}

complete block design. The first factor is the sources of shoot cuttings $(\mathrm{S} 1=$ Sources of shoot cuttings from plantlet, S2 $=$ Sources of shoot cuttings from tuber G0, S3 = Sources of shoot cuttings from tuber G1). The second factor is planting distance $(\mathrm{J} 1=80 \mathrm{~cm} \times 15 \mathrm{~cm}, \mathrm{~J} 2=$ $80 \mathrm{~cm} \times 20 \mathrm{~cm}$ and $\mathrm{J} 3=80 \mathrm{~cm} \times 25 \mathrm{~cm}$ ) with three replication. The experiment included the preparation of shoot cuttings, land management, making mounds, setting of spacing, planting, fertilizing, watering, replanting, weeding, piling, polling, controlling pests \& diseases and harvesting (after 100 days). Preparation of the sources of shoot cuttings are carried out: a) Planting of tuber or plantlet in husk charcoal media, acclimatization for planlet before planting, b) Cuttings of shoot c) Give Root Up before rooted cuttings d) Rooted cuttings f) Transplanting in field (can be seen in Figure 01).

The plant responses were measured on percentage of growth $(\%)$, plant height $(\mathrm{cm})$ and canopy width $(\mathrm{cm})$ at 70 days after planting , number of tubers per plant, number of tubers per class $(\mathrm{knol})$, tuber diameter $(\mathrm{cm})$, tuber weight per plant (gram), tuber weight per plot (gram) and the data on growth and yield component were collected from five samples randomly. Furthermore, the data were analysed statistically by $\mathrm{F}$ test at the $5 \%$ significance. When anova showed significant differences such will be followed by the Duncan Multiple Range Test (DMRT) at 5\% level.

\section{RESULTS AND DISCUSSION}

The analysis of variance for growth and yield component indicated that there were no significant interactions between the sources of shoot cuttings (plantlets, G0, G1) and planting distance $(80 \mathrm{~cm} \times 15 \mathrm{~cm}, 80 \mathrm{~cm} \mathrm{x} 20 \mathrm{~cm}$ and $80 \mathrm{~cm} \times 25 \mathrm{~cm})$. The highest percentage of growth $(97.72 \%)$ was produced by the sources of shoot cuttings from G0 and not significantly different (Table 01). Environmental factors such as water, nutrients, light, temperature and humidity support much to the growth of potato plants. 
Table 01: Growth Component of G2 Potato Seed (Solanum tuberosum L.) from the Different of Shoot Cuttings Sources and Planting Distance

\begin{tabular}{cccc}
\hline Treatment & Percentage of Growth (\%) & Plant Height $(\mathrm{cm})$ & Canopy Width $(\mathrm{cm})$ \\
\hline Shoot Cuttings Sources (S) & & & \\
\hline s1 (Plantlet) & $92.21 \mathrm{a}$ & $67.48 \mathrm{~b}$ & $35.92 \mathrm{~b}$ \\
s2 (G0) & $97.72 \mathrm{a}$ & $81.68 \mathrm{c}$ & $33.87 \mathrm{~b}$ \\
s3 (G1) & $85.39 \mathrm{a}$ & $53.93 \mathrm{a}$ & $28.74 \mathrm{a}$ \\
\hline Planting Distance (J) & & & \\
\hline j1 $(80 \times 15 \mathrm{~cm})$ & $90.43 \mathrm{a}$ & $66.84 \mathrm{a}$ & $32.11 \mathrm{a}$ \\
j2 $(80 \times 20 \mathrm{~cm})$ & $91.77 \mathrm{a}$ & $69.03 \mathrm{a}$ & $32.51 \mathrm{a}$ \\
j3 $(80 \times 25 \mathrm{~cm})$ & $93.12 \mathrm{a}$ & $67.23 \mathrm{a}$ & $33.91 \mathrm{a}$ \\
\hline
\end{tabular}

The sources of shoot cuttings (plantlet, G0 and G1) produced significantly different plant height and canopy width. The highest plants was produced by the sources of shoot cuttings from G0 (Table 01). The good response from the source of cuttings G0 on the percentage of growth $(97.72 \%)$, plant height $(81.68 \mathrm{~cm})$ and canopy width $(33.87 \mathrm{~cm})$ due to the shoot cuttings G0 are larger than the shoot cuttings plantlet. Photosynthate contained in the G0 tuber stimulate to the growth of shoot cuttings so that the size of organ is larger. Several factors affecting to the growth, development and yield of potato, including the availability of nutrients, cultivar, plant density, and environmental conditions (Bani-Hani et al., 2018)

By using of shoot cuttings sources (plantlet, G0 and G1) produce the yield components significantly different. The source of shoot cuttings from G0 produce the maximum tuber weight per plant (237.27 gram) and the maximum tuber weight per plot $(4.15 \mathrm{~kg})$ (Table 02) and (Figure 02). The higher growth component contained the more photosynthates so that produced the more tuber formation and tuber filling mechanisms (Arifin et al., 2014). According to (Rogi et al., 2016) the growth rate of tuber is the result of photosynthate depictions that was produced by plants per unit of time and space.

The highest number of tubers per plant was obtained from the sources of shoot cuttings from plantlet (7.88 pieces) followed by the sources of shoot cuttings G0 (5.24 pieces). The number of tubers per plant is influenced by genetic factors and environment. (Muthoni et al., 2017) reported that using starter plant material (in vitro-plantlet, stem cuttings dan minituber) on minituber production of two potato cultivar under aeroponics condition indicated that the stater material has a significant effect on the number of potato minituber produced. Use of in vitro planlets as starter material optimizes minituber production. The widest tuber diameter was obtained from the shoot cuttings sources of G1 (Table 02). Seed generation also affects the formation of stolons per plant and the number of stolons that will become tubers. The higher generation of seeds produces the number of stolons that will be smaller. The formation of stolons is influenced by several factors including planting depth, seed tuber size, soil moisture and nutrients (Utami et al., 2015). Usually, the little number of stolons produces large tuber size, while the more number of stolons produces small tuber size.The smaller tuber size very preferred by farmers as seed because they can save on production costs.

By using of planting distance $(80 \mathrm{~cm} \times 15 \mathrm{~cm}, 80$ $\mathrm{cm} \times 20 \mathrm{~cm}$ and $80 \mathrm{~cm} \times 25 \mathrm{~cm}$ ) it produced the growth components (growth percentage, plant height and canopy width) and yield components (number of tubers per plant, tuber diameter, tuber weight per plant and tuber weight per plot) which were not significantly different (Table 01) and (Table 02). In this case the treatment of planting distance has not caused competition between plants, both water, nutrients, and sunlight competition. The arrangement of planting distance provides an advantage to the individual plants in access to water, nutrients and sunlight ( Hossain et al., 2015). The narrow planting distance $(80 \mathrm{~cm} \times 15 \mathrm{~cm})$ tends produce the higher number of tubers per plant 
but the lower tuber weight per plant due to inter plant competition for water, light and nutrients. According to (Fayera, 2017) it is reported that the narrower spacing produced numerous small size potatoes. While the widest planting distance $(80 \mathrm{~cm} \times 25 \mathrm{~cm})$ tends to produce the higher tuber weight per plant (171.31 gram) and tuber weight per plot $(2.81 \mathrm{~kg})$ (Table 02). This is due to the planting distance $(80 \mathrm{~cm} \times 25 \mathrm{~cm})$ that has a better availability of nutrients, water and sunlight during plant growth thereby increasing tuber weight per plant and tuber weight per plot (Akassa et al, 2014)65, 70, 75, 80 and $85 \mathrm{~cm}$ and three levels of intra row spacings: 20, 30 and $40 \mathrm{~cm}$. According to (Bani-Hani et al., 2018)quality and water use efficiency. Little information describing plant density to optimize yield and quality of potato production is available in the Jordan Valley. This study was aimed to investigate the effects of plant density on the yield and yield components of the potato
(Solanum tuberosum L. the weight of tuber tend to be higher in plant and were grown at a low density due to experiencing less competition so that more resources to each separate tuber to produce a higher tuber weight. Means in the column followed by the same letter in Table 01, Table 02 , and Table 03 shows no significant difference in DMRT level of 5\%.

The number of tubers per class was obtained from the source of shoot cuttings from plantlet consist of super small, small, and medium $(91.83 \%)$ that can be used as G2 seeds, while the number of tubers per class "large" $(8.17 \%)$ can be used for tuber consumption (Table 03). The number of tubers per class was obtained from the source of shoot cuttings G0 consist of super small, small, and medium (74.43\%) that can be used as G2 seeds, while the number of tubers per class "large" $(25.57 \%)$ can be used for tuber consumption (Table 03).

Table 02: $\quad$ Yield Component of G2 Potato Seed (Solanum tuberosum L.) from the Different of Shoot Cuttings Sources and Planting Distance

\begin{tabular}{ccccc}
\hline Treatment & $\begin{array}{c}\text { Number of Tubers per } \\
\text { Plant (piece) }\end{array}$ & $\begin{array}{c}\text { Tuber Diameter } \\
(\mathrm{cm})\end{array}$ & $\begin{array}{c}\text { Tuber Weight per } \\
\text { plant (gram) }\end{array}$ & $\begin{array}{c}\text { Tuber Weight per } \\
\text { Plot (kg) }\end{array}$ \\
\hline Shoot Cuttings Sources $(\mathrm{S})$ & & & & \\
\hline s1 (Plantlet) & $7.88 \mathrm{c}$ & $2.92 \mathrm{a}$ & $142.33 \mathrm{a}$ & $2.47 \mathrm{~b}$ \\
$\mathrm{~s} 2(\mathrm{G} 0)$ & $5.24 \mathrm{~b}$ & $3.91 \mathrm{~b}$ & $237.27 \mathrm{~b}$ & $4.15 \mathrm{c}$ \\
s3 (G1) & $2.50 \mathrm{a}$ & $4.00 \mathrm{~b}$ & $118.39 \mathrm{a}$ & $1.39 \mathrm{a}$ \\
\hline Planting Distance $(\mathrm{J})$ & & & & \\
\hline j1 $(80 \times 15 \mathrm{~cm})$ & $6.03 \mathrm{a}$ & $3.53 \mathrm{a}$ & $163.34 \mathrm{a}$ & $2.48 \mathrm{a}$ \\
$\mathrm{j} 2(80 \times 20 \mathrm{~cm})$ & $4.60 \mathrm{a}$ & $3.62 \mathrm{a}$ & $163.33 \mathrm{a}$ & $2.72 \mathrm{a}$ \\
j3 $(80 \times 25 \mathrm{~cm})$ & $5.00 \mathrm{a}$ & $3.68 \mathrm{a}$ & $171.31 \mathrm{a}$ & $2.81 \mathrm{a}$ \\
\hline
\end{tabular}

Table 03: $\quad$ Number of Tubers per Class of G2 Potato Seed (Solanum tuberosum L.) from the Different of Shoot Cuttings Sources and Planting Distance

\begin{tabular}{|c|c|c|c|c|c|c|c|c|}
\hline \multirow{2}{*}{ Treatment } & \multicolumn{8}{|c|}{ Number of Tubers per Class (Knol) } \\
\hline & \multicolumn{2}{|c|}{ Super small $<20$ gram } & \multicolumn{2}{|c|}{ Small $(21-30)$ gram } & \multicolumn{2}{|c|}{ Medium $(31-60)$ gram } & \multicolumn{2}{|c|}{ Large $>60$ gran } \\
\hline \multicolumn{9}{|c|}{ Shoot Cuttings Sources(S) } \\
\hline \multirow[t]{2}{*}{ s1 (Plantlet) } & 5.08 & $\mathrm{c}$ & 1.13 & a & 1.88 & $\mathrm{~b}$ & 0.72 & $\mathrm{a}$ \\
\hline & $(57.66 \%)$ & & $(12,81 \%)$ & & $(21.34 \%)$ & & $(8.17 \%)$ & \\
\hline \multirow[t]{2}{*}{ s2 (G0) } & 2.68 & $\mathrm{~b}$ & 0.69 & a & 1.55 & $a b$ & 1.69 & $\mathrm{~b}$ \\
\hline & $(4.54 \%)$ & & $(10.44 \%)$ & & $(23.45 \%)$ & & $(25.57 \%)$ & \\
\hline \multirow[t]{2}{*}{ s3 (G1) } & 1.24 & a & 1.07 & a & 1.11 & a & 1.22 & $\mathrm{~b}$ \\
\hline & $(26.72 \%)$ & & $(23.06 \%)$ & & $(23.92 \%)$ & & $(26.29 \%)$ & \\
\hline \multicolumn{9}{|c|}{ Planting Distance $(\mathrm{J})$} \\
\hline \multirow[t]{2}{*}{$\mathrm{j} 1(80 \times 15 \mathrm{~cm})$} & 3.53 & a & 0.94 & a & 1.54 & a & 1.23 & a \\
\hline & $(48.76 \%)$ & & $(12.98 \%)$ & & $(21.27 \%)$ & & $(16.99 \%)$ & \\
\hline \multirow[t]{2}{*}{$\mathrm{j} 2(80 \times 20 \mathrm{~cm})$} & 2.65 & $\mathrm{a}$ & 1.10 & $\mathrm{a}$ & 1.37 & $\mathrm{a}$ & 1.23 & $\mathrm{a}$ \\
\hline & $(41.73 \%)$ & & $(17.32 \%)$ & & $(21.57 \%)$ & & $(19.37 \%)$ & \\
\hline \multirow[t]{2}{*}{$\mathrm{j} 3(80 \times 25 \mathrm{~cm})$} & 2.82 & $\mathrm{a}$ & 0.85 & a & 1.61 & $\mathrm{a}$ & 1.17 & a \\
\hline & $(43.72 \%)$ & & $(13.17 \%)$ & & $(24.96 \%)$ & & $(18.14 \%)$ & \\
\hline KK (\%) & & & $21.57 \%$ & & $17.51 \%$ & & $18.68 \%$ & \\
\hline
\end{tabular}




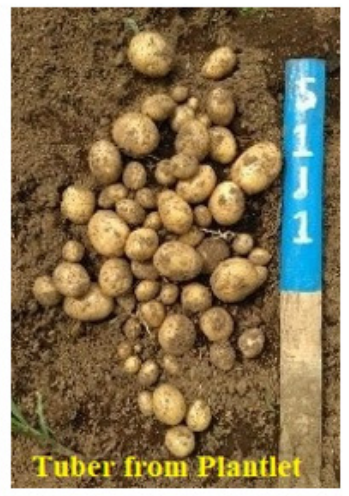

A

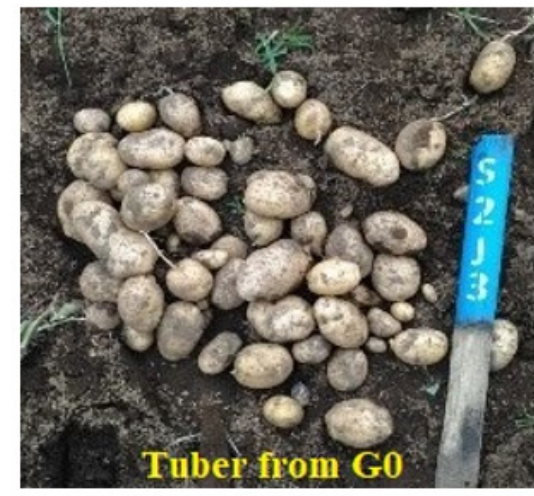

B

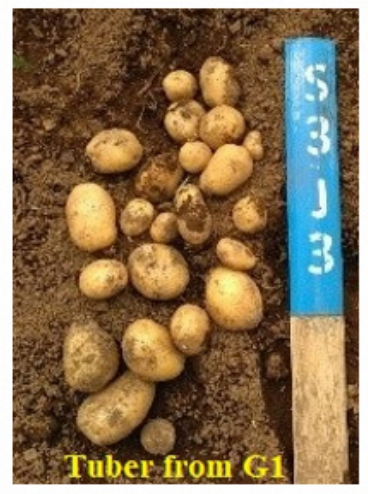

$\mathrm{C}$

A). Tuber yield from plantlet; B) Tuber yield from G0; C). Tuber yield from G1.

Figure 02: $\quad$ Yield of potato from the shoot cuttings sources (Plantlet, G0,G1)

\section{CONCLUSION}

There were no significant interactions between the sources of shoot cuttings (plantlets, G0, G1) and planting distance $(80 \mathrm{~cm} \mathrm{x} 15 \mathrm{~cm}$, $80 \mathrm{~cm} \times 20 \mathrm{~cm}$ and $80 \mathrm{~cm} \times 25 \mathrm{~cm})$. The source of shoot cuttings from G0 produces the highest percentage of growth $(97.72 \%)$, plant height $(81.68 \mathrm{~cm})$, canopy width $(33.87$ $\mathrm{cm})$, maximum tuber weight per plant $(237.27$ gram) and maximum tuber weight per plot (4.15 $\mathrm{kg}$ ). The source of shoot cuttings from plantlet produces the highest number of tubers per plant (7.88). By using planting distance $(80 \mathrm{~cm} \times 25$ $\mathrm{cm})$ tends to have better for tuber weight per plant (171.31 gram) and tuber weight per plot $(2.81 \mathrm{~kg})$.

\section{Data Availability Statement}

All data generated or analysed during this Study are included in this published article and are available with supplementary information files.

\section{ACKNOWLEDGMENT}

The authors are grateful to Indonesian Vegetables Research Institute (IVEGRI) for the experimental garden and laboratory facilities and their colleagues at IVEGRI especially Mr.Deden Fathullah who helped during the research. The authors are also thankful to LLDIKTI west java, Chancellor of Winaya Mukti University (UNWIM), their colleagues from the UNWIM Faculty of Agriculture, and Family for the support.

\section{REFERENCES}

Akassa, B., Belew, D., \& Debela, A. (2014). Effect of Inter and Intra Row Spacing on Potato (Solanum tuberosum L.) Seed and Ware Tuber Seedling emergence and establishment at bako, Western Ethiopia. Journal of Agronomy, 13(3), 127-130. DOI: https://doi.org/10.3923/ ja.2014.127.130

Arifin, M. S., Nugroho, A., \& Suryanto, A. (2014). Study of Shoot Lenght and Seed Tuber Weight on Increase Yield Potato Plants (Solanum tuberosum L.) Granola Variety. 2(April), 221229. Retrieved from https://media.neliti.com/media/publications/127630-ID

Badan Pusat Statistik, H. (2017). Statistik Tanaman Buah-buahan dan Sayuran Tahunan Indonesia. Badan Pusat Statisik.

Bani-Hani, N. M., Al-Tabbal, J. “Ahmed S., Haddad, M. A., Aldal'in, H. K., Al-Fraihat, A. H., Alhrout, H. H., Aldabbas, F. M. (2018). Effect of Plant Density on the Water Use Efficiency and Quality of Potato (Solanum tuberosum L. Cv. Spunta) in the Jordan Valley. Journal of Agricultural Science, 10(12), 203. DOI: https://doi.org/10.5539/jas.v10n12p203 
Dahshan, A.M.A., Zaki, H.E.M., Y.M.M., \& Moustafa, Mageed Y.T.A., Hassan, M.A.M. (2018). Using Stem Tip Cuttings in Potato Production. Minia J. of Agric. Res. \& Develop., 38(April), 363-389. Retrieved from https://www.researchgate.net/publication/329371871

Direktorat Perbenihan Hortikultura. (2014). Teknis, Perbanyakan dan Sertifikasi Benih Kentang. Retrieved from https://adoc.tips/teknis-perbanyakan-dan-sertifikasi-benih-kentang.html

Fayera, W. N. (2017). Yield and Yield Components of Potato (Solanum tuberosum L.) as Influenced by Planting density and Rate of Nitrogen Application at Holeta, West Oromia region of Ethiopia. African Journal of Agricultural Research, 12(26), 2242-2254. DOI: https://doi. org/10.5897/ajar2016.11840

Harahagazwe, D., Andrade-piedra, J., \& Schulte-geldermann, E. (2018). Current Situation of Rapid Multiplication Techniques for Early Generation Seed Potato Production in Sub- Saharan Africa. CGIAR Research Program on Roots, Tubers and Bananas (RTB)., (RTB Working Paper. No. 2018-1.). DOI: https://doi.org/10.4160/23096586RTBWP20181

Hossain, M. A.,Abdullah-Al-Mahmud, Md. Abdullah-Al-Mamun, Md. Shamimuzzaman, M. M. R. (2015). Optimization of Minituber Size and Planting Distance for the Breeder Seed Production of Potato. American Journal of Agriculture and Forestry, 3(2), 58-64. DOI: https://doi.org/10.11648/j.ajaf.20150302.18

Karjadi, A. K. (2017). Teknik Perbanyakan Cepat Tanaman Kentang (Solanum tubeosum L). IPTEK, (014), 1-9.

Mamun, M. A. Al, Mahmud, A. Al, Khan, M. S. A., Hossain, M. A., \& Zakaria, M. (2015). Planting Time Effects of Top-Shoot Cutting on Yield and Grade for Rapid Seed Potato Multiplication. OALib, 2(9). DOI: https://doi.org/10.4236/oalib.1101904

Muthoni, J., Mbiyu, M., Lungaho, C., Otieno, S., \& Pwaipwai, P. (2017). Performance of Two Potato Cultivars Derived from In-vitro Plantlets, Mini-tubers and Stem Cuttings Using Aeroponics Technique. International Journal of Horticulture, 7(27). DOI: https://doi. org/10.5376/ijh.2017.07.0027

Rogi, J. E. X., Kembuan, H. S. G., \& Rombang, J. A. (2016). Laju Tumbuh Umbi Tanaman Kentang Varietas Granola dan Supejohn di Dataran Medium dengan Pemulsaan. Jurnal Hortikultura Indonesia, 7(2), 83. DOI: https://doi.org/10.29244/jhi.7.2.83-90

Salem,J And A. Hassanein. (2017). In vitro Propagation, Microtuberization, and Molecular Characterization of three Potato Cultivars .No Title. Biologia Plantarum, 61(3), 427-437. Retrieved from https://scholar.google.com.eg/citations

Sibongile, C. Z., Joyce, P. N., Jacinta, A. N., Weston, F. M., Moses, F. M., James, M. B., \& Moses, B. K. (2014). Minituber Production Potential of Selected Potato (Solanum tuberosum L.) Genotypes in Different Propagation Media. African Journal of Biotechnology, 13(48), 4430-4437. DOI: https://doi.org/10.5897/ajb2014.13740

Utami, gina rahma, Rahayu, megayani sri, \& Setiawan, A. (2015). Penanganan Budidaya Kentang (Solanum tuberosum L.) di Bandung, Jawa Barat Handling of Potato Cultivation (Solanum tuberosum L.) at Bandung, West Java. Agrohorti, 3(1), 105-109. Retrieved from https:// journal.ipb.ac.id/index.php/bulagron/article/view/14833/10944 
Yasmin, M.F.M., and Zakaria. (2019). Effect of Planting Time and Density of Top Shoot Cuttings in Potato Production. International Journal of Natural and Social Sciences, 6(1), 60-68. DOI: https://doi.org/doi.org/10.1016/j.anres.2014.08.001

Zerga, K., Getu, B., and Mohammed, K. (2017). Effects of Intra-Row Spacing on Vegetative Growth Performance of Potato (Solanumtuberosum L). Ethiopia. International Journal of Photochemistry and Photobiology, 2(4), 108-112. DOI: https://doi.org/10.11648/j. ijpp.20170204.12 